\title{
URUTU-BRANCO E O LEPROSO: CORPO E CULPA EM UMA VEREDA DO GRANDE SERTÃO
}

\author{
Raquel Illescas Bueno*
}

O INFERNO

[...]

SEJAS TU GRAMÁTICA

OU GUERRA

CAMPOS DO JOGO, SEVERA CABALÍSTICA

MECÂNICA DE FEDORES

[...]

E podes comer esta pele

com tua floração de lepra.

É que eu mesmo sou ELE e o seu deslumbro,

é que eu sou sua veste e seu canto, e o brilho

- que encravado na carne,

sustenta-o, LUGKS,

matilha acesa,

CONSUMAÇĀO EM SÓIS DE POEIRA E FOME DOS PUDORES.

Ferreira Gullar

O inferno dos vivos não é algo que será; se existe, é aquele que já está aqui, o inferno no qual vivemos todos os dias, que formamos estando juntos. Existem duas maneiras de nāo sofrer. A primeira é fácil para a maioria das pessoas: aceitaro inferno e tornar-se parte deste até o ponto de deixar de percebê-lo. A segunda é arriscada e exige atençāo e aprendi

zagem contínua: tentar saber reconhecer quem e o que, no meio do infermo, não é inferno, e preservá-lo, e abrir espaço. Italo Calvino. As cidades invisiveis

* Universidade Federal do Paraná 


\section{Grande sertão: veredas: a tentação do ilimitado}

O pacto com o demônio - assunto central de Grande sertão: veredas ${ }^{1}$ talvez não se tenha aperfeiçoado no plano físico, como Riobaldo pensava que pudesse ocorrer quando se dirigiu à encruzilhada das Veredas-Mortas. Esse assunto, porém, alçado a tema e com participação na problemática da luta entre o Bem e o Mal, dissemina-se em inúmeros motivos a partir dos quais Guimarães Rosa construiu o discurso e a personalidade de Riobaldo. Dos importantes temas a-históricos abordados no romance, interessa destacar os seguintes: a culpa, relacionada ao corpo; a existência ou não de Deus e do Diabo; o medo da morte.

Este texto analisa o encontro do protagonista com um leproso, ${ }^{2}$ ocorrido quando Riobaldo já se tornara o chefe Urutu-Branco e firmava-se na liderança do bando. Logo depois, ele conduziria seus homens na travessia vitoriosa do Liso do Suçuarão. O episódio, carregado de simbolismo, propicia reflexões acerca dos limites do humano. Riobaldo esboça ponderações de natureza ética e moral sobre os limites do corpo, colocados à prova pela doença: até que ponto um corpo totalmente tomado pela lepra ainda é um corpo de "homem humano"?

É possível pensar, por contraste, sobre os limites da consciência humana em seu afã de reconhecer, no inferno do cotidiano, ações que possam resultar no combate daquilo que, no meio do humano, é quase inumano. No final do episódio, os corpos (e as consciências) já não são corpos contaminados pela lepra, mas sim o dele próprio e o de Diadorim.

$\mathrm{O}$ pacto aprofundou as contradições e as dúvidas do protagonista, podendo ser considerado, a um tempo, rito iniciático e instauração de verdadeiro drama fáustico. ${ }^{3}$ Ampliaram-se, depois dele, a "ambigüidade" e a "mistura" de que tratam Antonio Candido, Walnice Galvão e Davi Arrigucci. ${ }^{4}$ Assumindo os riscos da condição de pactário, Riobaldo tornou-se chefe e aproximou-se do heroísmo épico que antes lhe aparecia nas figuras de Medeiro Vaz, Joca Ramiro e Zé Bebelo. O final do romance, trazendo, a um tempo, a vitória sobre o Hermógenes e a morte de Diadorim, resultou no desejo de Riobaldo de atribuir significação a tudo o que viveu enquanto jagunço e a cada história relatada. A

1 ROSA, Guimarães. Grande sertão: veredas. Rio de Janeiro: Nova Fronteira, 1986. (Todas as citações do romance foram extraídas dessa edição.)

2 lbid., p. 459-463.

3 SCHWARZ, Roberto. Grande sertão e Dr. Faustus. In: A sereia e o desconfiado. São Paulo: Duas Cidades, 1981.

4 CANDIDO, Antonio. O homem dos avessos. $\mathrm{ln}$ : Tese e antítese. São Paulo: Nacional, 1964; GALVĀO, Walnice Nogueira. As formas do falso. São Paulo: Perspectiva, 1986; ARRIGUCCI Jr, Davi. O mundo misturado: romance e experiência em Guimarães Rosa. In: América Latina: Palavra, Literatura e Cultura. v. 3. 
narração possibilita a Riobaldo, dentre outras coisas, investigar sua culpabilidade.

O aperfeiçoamento do sentido trágico da trajetória de Riobaldo deu-se com a morte de Diadorim e a conseqüente revelação de sua condição de moça virgem. Impossibilitado de conviver com Maria Deodorina, Riobaldo buscará consolo e esclarecimento na religião, seja ela qual for: "Eu cá, não perco ocasião de religião. Aproveito de todas. Bebo água de todo rio..." (p. 15). Ainda assim, predomina a desordem mental que torna o relato cheio de idas e vindas. Nesse impressionante quebra-cabeças de episódios, Riobaldo busca o esclarecimento e a paz interior. No corpo, ele sente algumas dores reumáticas, mas sua vida em geral é tranqüila. O tempo de "range rede" possibilita a fantasia, porque reúne a estabilidade econômica, o convívio ameno com Otacília, o treino da pontaria apenas como hobby e a vizinhança com velhos companheiros de jaguncismo que, apesar de estarem, como ele, "aposentados", estão prontos a prestar apoio.

Riobaldo entrou e saiu do jaguncismo menos por inclinação pessoal do que em função de Diadorim (sua "neblina") e das contingências históricas de um tempo que já é passado quando se inicia a narração. Há muito o que narrar, e ele convida seu interlocutor a permanecer alguns dias por ali, até porque Riobaldo sempre valorizou o estudo e as "cartas de doutor", e adivinhava que o "senhor" para quem falava pudesse ser capaz de compreensão e cumplicidade, o que fica confirmado ao final do relato: "Amável o senhor me ouviu, minha idéia confirmou: que o Diabo não existe. Pois não? O senhor é um homem soberano, circunspecto. Amigos somos. Nonada. O diabo não há! É o que eu digo, se for... Existe é homem humano. Travessia." (p. 568)

Se for... Mas, e se não for? O relato não se fecha, a única certeza - a travessia - é móvel, provisória e relativa, como todas as "certezas" possíveis na modernidade. ${ }^{5}$ Nas palavras de Italo Calvino, em Seis propostas para o próximo milênio: "Hoje em dia não é mais pensável uma totalidade que não seja potencial, conjectural, multíplice." Grande sertão: veredas é bom exemplo do que Italo Calvino denominou "enciclopédia aberta", forma de romance característico do século 20.

"Apologia do romance como grande rede", como o definiu o próprio Calvino, seu ensaio sobre a multiplicidade caminha na contramão de grande parte da crítica, pois o autor elegeu a própria multiplicidade e a "excessiva

5 Davi Arrigucci Jr. aprofundou a análise da modernidade de Grande sertão: veredas no ensaio anteriormente citado (O mundo misturado: romance e experiência em Guimarães Rosa. In: América Latina: Palavra, Literatura e Culura, v. 3).

6 CALVINO, Italo. Seis propostas para o próximo milênio. São Paulo: Companhia das Letras, 1990. p. 131. 
ambição de propósitos" como valores positivos em literatura, considerando que essa ambição não afasta a obra "daquele unicum que é o self de quem escreve". 7 Se cada vida é uma enciclopédia aberta "onde tudo pode ser continuamente remexido e reordenado de todas as maneiras possíveis", por que se deveria exigir do romance algum fechamento? Talvez a tentação do ilimitado tenda a ser mais realista do que os recortes ditados por alguma obsessão de unidade. Os leitores de Grande sertão: veredas sentem-se constantemente desafiados a avaliar o que se aperfeiçoa e o que permanece em aberto, ou desfeito, na trajetória de Riobaldo.

Grande sertão: veredas recebeu diversas leituras que, investigando aspectos metafísicos, procuram revelar uma unidade final no romance, seja identificando no percurso de Riobaldo um roteiro rumo à conversão (é o caso de $O$ roteiro de Deus, de Heloisa Vilhena de Araujo ${ }^{8}$ ), seja interpretando cada passagem desse percurso como avanço nas trilhas da iniciação esotérica (como em Bruxo da linguagem no Grande sertão, de Consuelo Albergaria, Metafísica do Grande sertão, de Francis Utéza, e Riobaldo Rosa: a vereda junguiana do Grande sertão, de Tania Rebelo Costa Serra ${ }^{9}$ ). Outros textos críticos, por outro lado, demonstram alguma desconfiança em relação a essas leituras, apontando nelas a tendência à "divinização" de Riobaldo.

A confusão e a mistura fazem parte da própria estrutura geral do romance, mas nem por isso contaminam cada um dos personagens e espaços. Assim também, alguns episódios narrados revelam-se claros, pouco ambíguos quanto à função que exercem, ainda que colaborem decisivamente para a ambigüidade do texto como um todo. Otacília, por exemplo, fixa-se como personagem ligada ao plano de Deus; Hermógenes, como pactário do Diabo. O Guararavacã do Guaicuí permanece como locus-amoenus; o Paredão, como local maldito (ao contrário, por exemplo, das Veredas-Mortas, que se metamorfoseiam em Veredas-Altas, ou do Liso do Suçuarão, que se transforma juntamente com a transformação de Riobaldo). Dentre as "histórias exemplares", há as mais complexas, como a de Maria Mutema, mas outras são breves e lineares, como a da conversão de Joé Cazuzo em meio à batalha após uma visão da Virgem. Já

7 CALVINO, op. cit., p. 138.

8 ARAUJO, Heloisa Vilhena de. O roteiro de Deus. São Paulo: Mandarim, 1996.

9 ALBERGARIA, Consuelo. Bruxo da linguagem no Grande sertão. Rio de Janeiro: Tempo Brasileiro, 1977; UTÉZA, Francis. JGR: metafísica do Grande sertão. São Paulo: Edusp, 1994; SERRA, Tania R. C. Riobaldo Rosa: a vereda junguiana do Grande sertão. Brasilia: Thesaurus, 1990.

10 É o caso, por exemplo, da dissertação de mestrado de Marilia Librandi Rocha, intitulada As espantosas palavras; uma análise de Grande sertão: veredas (São Paulo, 1997. Faculdade de Filosofia, Letras e Ciências Humanas da Universidade de São Paulo). 
o episódio selecionado, apesar de breve, é altamente simbólico, e, mesmo quando lido isoladamente, revela a natureza ambígua da cosmovisão de Riobaldo.

O final do romance destaca o valor da travessia. Pode-se entender a travessia como conciliação dos opostos, resultando em síntese que aproxima o homem da plenitude. Pode-se, também, entendê-la como mais um dos elementos da "mistura". Afinal, realizá-la é mais um dos desafios a ser enfrentado por um "herói problemático" (para empregar a terminologia de Lukács). A ausência de controle sobre a travessia e o desejo de minimizar seus efeitos nefastos definem a condição humana, problemática.

\section{A tentação de Riobaldo}

Nem os cavaleiros medievais, nem os heróis clássicos escapam ao fado. Ocorre que os heróis - inclusive os "heróis problemáticos" - às vezes dispõem do poder de vida e morte sobre outras personagens. Quando um leproso em fase terminal atravessa uma vereda, fazendo Riobaldo defrontar-se com o nível mais abjeto da existência física, ocorre a ele que interromper aquela vida talvez fosse uma forma de "emendar o defeituoso".

Poupar o doente da morte não foi uma decisão totalmente consciente de Riobaldo, mas sim o resultado da escuta de uma voz de advertência que ele identificava como proveniente de Diadorim. O final do episódio trouxe a confirmação da amizade entre ambos, após um período de relativo afastamento, causado pelos excessos que Riobaldo estava inclinado a cometer após o pacto. Riobaldo, por sua vez, queixava-se de Diadorim, que não externava reconhecimento por seus feitos heróicos (como, por exemplo, o auxílio a uma parturiente, narrado com ares de intervenção milagrosa).

Percebendo que Riobaldo estava tentado a matar gratuitamente, Diadorim alertou: "o que está demudando, em você, é o cômpito da alma - não é razão de autoridade de chefias..." (p. 437). Diadorim também mandou recado, pedindo para que Otacília rezasse por seu amigo. A atitude de Riobaldo ao tomar conhecimento desse fato foi grosseira: "'Acha tua vida, rapaz! Careço é de menos amizades...'. Rezas essas, o contra? Atira, tu em anta com chumbo fino... - e ri màmente." (p. 451). Nesse cômpito (encruzilhada) de alma, a natureza cordial do protagonista cedia espaço para a desconfiança e o desdém. Mesmo no final do episódio selecionado, em que há uma reaproximação entre ambos, Riobaldo faz questão de manter-se à frente e de comandar a ação: "Assim eu dava ordem, como convinha." (p. 463) 
Logo depois do encontro com o leproso, aconteceu a deserção dos urucuianos. Interpretando-a como mau agouro, Riobaldo passa a desejar que todos rezem por ele. Seu objetivo era aperfeiçoar a liderança para liquidar o Hermógenes. Mesmo assim, antes de atravessar o Liso do Suçuarão, Riobaldo conduziu o bando de forma a adiar o encontro, dando voltas aparentemente injustificadas. Ele completava sua preparação de chefe ("Eu já estava chefe de glórias" - p. 469), preparava-se para casar com Otacília, mas sentia a incompletude maior em razão da ambigüidade de seus sentimentos por Diadorim.

A comparação entre os três episódios em que Riobaldo se vê tentado a matar permite distinguir o tom e os registros predominantes em cada um deles, e mostra, no episódio selecionado, uma evolução da total gratuidade do desejo de assassinato ao aprofundamento da temática da culpa.

No primeiro episódio, a vítima seria Constâncio Alves, um homem de posses, bem falante, que acreditava ter conhecido Riobaldo no passado. Apesar do "doido afã de matar aquele homem, tresmatado"(p. 439), Riobaldo resistiu três vezes. Na primeira, atendeu a uma vozinha vinda do "sobredentro de [suas] idéias". Na segunda, clamou pela Virgem e, em seguida, resolveu jogar com o acaso, propondo a si próprio que, caso Constâncio Alves conhecesse um tal Gramacêdo (que é mencionado no início do romance como o primeiro homem de quem o menino Riobaldo sentira ódio), seria morto; senão, estaria salvo. Constâncio Alves afirmou que não conhecia, escapando da morte pela segunda vez. No terceiro momento de tentação, Riobaldo resistiu porque lhe ocorreu que "aquele homem merecia viver por causa de uma grande beleza no mundo". (p. 441)

A possível presença do demônio é mencionada, ora de forma mais auto-reflexiva ("o demo então era eu mesmo?"), ora de forma mais simbólica (faz-se referência à "luz de Lúcifer"). Durante a conversa entre Riobaldo e Constâncio Alves, ocorre a interferência do menino Guirigó (anteriormente chamado de "diabinho"). A representação do demônio inclui a hipótese quase cômica de um bando de diabinhos "mil e mil, tocando lindas violas", que, a mando do "demônio-mestre", tivessem distraído a consciência do herói. Esse tom não aparece em momento algum na narração do episódio do leproso.

Além de aspectos cômicos, o episódio tem algo do que Auerbach identificaria como "estilo baixo". Riobaldo aproveita a ocasião para pedir dinheiro a Constâncio Alves, o que permitiria ler o episódio, de maneira

11 Heloisa Vilhena, em $O$ roteiro de Deus, aponta uma seqüência de três tentações, e compara-a às tentaçōes de Cristo no deserto. Essa sequiência exclui o episódio do leproso, incluindo a tentação de Riobaldo de possuir a filha de Seo Ornelas, pouco antes do encontro com Constâncio Alves. (p. 178) 
redutora, como narrativa de um assalto a um viajante abonado, atitude muito comum naquele meio. O simbolismo do episódio - presente/passado/aprendizagem do ódio, riqueza/pobreza, tripla tentação (como no episódio bíblico) não afasta o realismo, presente, principalmente, na representação do cotidiano dos negócios de jagunços.

Tendo resistido, Riobaldo prometeu que, para "enterter o Outro", mataria o primeiro homem que aparecesse. Aproximam-se um homem, uma égua e uma cachorrinha. Riobaldo consulta o menino Guirigó e o cego Borromeu, mas permanece indeciso quanto ao cumprimento da promessa. Procura inspirar-se no exemplo de Zé Bebelo, chefe habilidoso nos acertos políticos, e inventa a hipótese de substituição da vítima, pois o primeiro ser avistado teria sido a cadela, ou a égua. Dois jagunços intervêm, cada um a favor de um dos animais. Por fim, Riobaldo encontra uma solução engenhosa: como tinha prometido matar um homem, e "égua não é gente", não haveria nenhuma morte.

Também aqui, o cômico encontra alguma brecha em meio à tensão. Forçando-se o tom, o argumento do episódio poderia fazer parte, por exemplo, do anedotário de Pedro Malazartes, especialista em armar situações confusas e livrar-se delas com esperteza, inclusive quando se tratava de negociar com o diabo. As personagens colaboram para o efeito cômico: um homem pobre, que permanece mudo, tentando se equilibrar sobre uma égua cambaia, e acompanhado por uma cachorrinha. A certa altura, a cena torna-se grotesca, pois o homem, apavorado, "dera de obrar, mesmo permeando para a sela, que se sujava" (p. 444). Os jagunços alternavam risos e irritação. A certa altura, o texto recupera a densidade dramática, e Riobaldo sente vontade de chorar para acompanhar o choro do homem, mas não consegue: "[...] no final da vez, o que ria o riso principal era ele, o demo." (p. 446-447)

Aos olhos dos companheiros, Riobaldo saiu fortalecido. Um jagunço louvou-lhe as artimanhas, dignas de Zé Bebelo; outro, "mais aduloso", comparou-o com Medeiro Vaz, exemplo maior de justiça na concepção de Riobaldo. Ele próprio sentiu-se livre, mas descontente consigo, e evitou pensar.

No episódio do leproso, ao contrário, apenas Diadorim presenciou a hesitação de Riobaldo, e nenhuma personagem pronunciou qualquer palavra que pudesse influenciá-lo ou que servisse como reconhecimento de sua resistência à tentação. A solidão moral das três personagens (Riobaldo, Diadorim e o leproso) é indicada, inclusive, pelo silêncio da cena. $O$ trecho anterior ao encontro mostra Riobaldo evitando que suas idéias clareassem junto com o dia, para que o remorso não pudesse se instaurar: 
O demo, tive raiva dele? Pensei nele? Em vezes. O que era em mim valentia, não pensava; e o que pensava produzia era dúvidas de me-enleios. Repensava, no esfriar do dia. A quando é o do sol entrar, que então até é o dia mesmo, por seu remorso. Ou então, ainda melhor, no madrugal, logo no instante em que eu acordava e ainda não abria os olhos: eram só os minutos, e, ali durante, em minha rede, eu preluzia tudo claro e explicado. Assim: - Tu vigia, Riobaldo, não deixa o diabo te pôr sela... - isto eu divulgava. Aí eu queria fazer um projeto: como havia de escapulir dele, do Temba, que eu tinha mal chamado. Ele rondava por me governar? Mas, então, governar pudesse, eu não era o Urutu-Branco, não vinha a ser chefe de nada, coisa nenhuma! Ah, eu carecia dum jeito, dum esperto socorro, para tentear com o Sujo em suas próprias portas, e mediante me pôr livre de fim fatal. De que modo?

Mas acontece que o instante entre o sono e o acordado era assaz curto, só perpassava, não dava pé. Eu não podia me firmar em coisa nenhuma, a clareza logo cessava. Daqueles avisos e propósitos, o montante movimento do mundo me delia, igual a um secar. E eu mesmo estava contra mim, o resto do tempo. Não estava? Todo o mundo, cada dia, me obedecia mais, e mais me exaltavam. Com o que, peguei, aos poucos, o costume de pular, num átimo, da rede, feito fosse para evitar aquela inteligencinha benfazeja, que parecia se me dizer era mesmo do meio do meu coração. Num arranco, desfazia aquilo - faísca de folga, presença de beija-flor, que vai começa e já se apaga - e daí já estava inteirado no comum, nas meias-alegrias: a meia-bondade misturada com maldade a meio. Agora levantava, puxava e arreava meu Siruiz, cavalo para alvoradas. Saía sozinho.

Sair na escuridão, o senhor sabe: aqueles galhos de árvores batendo na cabeça da gente. Sempre eu ia até longe; quando voltava, encontrava o pessoal se aprontando, café já coado, cavalaria em fila para a viagem. Uma vez, inda mais longe fui, do que nas outras. E dei com o lázaro. (p. 458-459)

\section{Seu corpo, sua culpa!}

Ele se achava como que tocaiando, no alto duma árvore, por se esconder, feito uma cobra ararambóia. [...]

Dum fato, na hora, me lembrei: do que tinham me contado, da vez em que Medeiro Vaz avistou um enfermo desses num goi- 
abal. $\mathrm{O}$ homem tinha vindo lamber de língua as goiabas maduras, por uma e uma, no pé, com o fito de transpassar o mal para outras pessoas, que depois comessem delas. Uns assim fazem. Medeiro Vaz, que era justo e prestimoso, acabou com a vida dele. (p. 459)

A apresentação do leproso remete ao mito do pecado original. Como a serpente que oferece o fruto proibido e instaura o pecado, o leproso é visto como alguém que pode espalhar o mal pelo mundo. Sedutora, capaz de levar Adão e Eva à luxúria, a serpente bíblica detém o conhecimento, fazendo Adão acreditar que a árvore da morte fosse a árvore da vida. Se o leproso lembrava uma ararambóia, Riobaldo era o Urutu-Branco, incorporando, ele também, algo da natureza da serpente. $O$ encontro de ambos sugere um dos aspectos positivos do simbolismo da serpente: sua "função ctoniana de executor da justiça divina". 12

O mal a ser eliminado, no caso, é a lepra, "doença maldita", sobre a qual sempre recaiu grande dose de preconceitos, que motiva a exclusão social dos doentes e de seus familiares. Até pouco tempo, acreditava-se que a lepra era doença altamente contagiosa. $O$ apodrecimento dos tecidos da pele causado pelo bacilo da lepra sempre causou um horror até certo ponto desproporcional à gravidade da doença. Sendo uma infecção visível (ao contrário de tantas outras, muitas delas mais contagiosas), e que exala odores fétidos, a doença impressiona fortemente os sentidos, por isso mete medo. No início da era cristã, os leprosos curados deveriam comparecer frente a um sacerdote que, atestando sua cura, lhes concederia o direito de voltar ao convívio social. Sabe-se que, no tempo das Cruzadas, época em que a doença se espalhou pela Europa (séculos 12 e 13), os doentes eram muitas vezes mortos pelo povo.

A mesma ausência de esclarecimento sobre a doença acontece, por exemplo, no sertão das Gerais, e poucos estiveram tão atentos a isso quanto o médico João Guimarães Rosa. Para citar exemplos de sua obra, a protagonista do conto "Substância", de Primeiras estórias, Maria Exita, filha de leproso, penava nas pedras do polvilho, rejeitada pelos rapazes, que temiam "a doença, incerta, sob a formosura"; ${ }^{13} \mathrm{em}$ "A terceira margem do rio", uma das primeiras hipóteses formuladas para explicar a partida do pai, na canoa, foi a de que ele "por escrúpulo de estar com alguma feia doença, que seja, a lepra, se desertava para outra sina de existir"; ${ }^{14}$ em Grande sertão: veredas, a simples suposição de que fosse portador dessa doença levava o jagunço Sô Candelário a despren-

12 CHEVALIER, Jean; GHEERBRANT, Alain. Dicionário de símbolos. Rio de Janeiro: J. Olympio, 1989. p. 824.

13 ROSA, Guimarāes. Primeiras estórias. Rio de Janeiro: Nova Fronteira, 1985. p. 140.

14 Ibid., p. 33. 
der-se da vida (ao apresentá-lo, no início do romance, Riobaldo diz que Sô Candelário "se endiabrou, por pensar que estava com doença má" - p. 16).

Outras doenças de pele compartilham com a lepra esse preconceito, mas nenhuma é tão imediatamente relacionada a alguma maldição. No Grande sertão, há referências à bexiga, que marcou grande parte dos habitantes do Sucruiú ("más marcas, feito mijo na areia"), e a um catrumano que "coçava suas costas em pau de árvore, feito um bezerro ou um porco". Assim como os estigmas e as chagas, qualquer marca na pele pode estar relacionada, no imaginário popular e religioso, a castigos por atos passados.

$\mathrm{Na}$ Divina comédia, os que penam sem alívio o "pungentíssimo e frenético prurido" da sarna e da lepra estão no último fosso do oitavo círculo do Inferno, e sabem quais foram seus crimes em vida: são os fraudulentos, imitadores e contrafatores. No Grande sertão, predomina a dúvida sobre a causa do castigo. Qual teria sido o mal praticado por Sô Candelário, ou pelo leproso?

Sô Candelário caçava era a morte. [...] ele tinha medo de estar com o mal-de-lázaro. Pai dele tinha adoecido disso, e os irmãos dele também, depois e depois, os que eram mais velhos. Lepra mais não se diz: aí é que o homem lambe a maldição de castigo. Castigo, de que? Disso é que decerto sucedia um ódio em Sô Candelário. Vivia em fogo de idéia. Lepra demora tempos, retardada no corpo, de repente é que se brota; em qualquer hora, aquilo podia variar de aparecer.

As favas fora, ele perseguia o morrer, por conta futura da lepra; e, no mesmo do tempo, do mesmo jeito, forcejava por se sarar. Sendo que queria morrer, só dava resultado que mandava sortes, e matava. Doido, era? Quem não é, mesmo eu ou o senhor? Mas aquele homem, eu estimava. Porque, ao menos, ele, possuía o sabido motivo. (p. 227-228)

Apesar da incômoda pressa de Sô Candelário em definir seu destino, sua atitude causa admiração, ou inveja, em Riobaldo. Aquele homem havia encontrado o "sabido motivo" para morrer, e isso o deixava em relativa vantagem sobre os outros mortais. Para Riobaldo, a paciência era um valor maior: " [...] 0 ruim com o ruim, terminam por as espinheiras se quebrar - Deus espera essa gastança. Moço!: Deus é paciência. O contrário é o diabo." (p. 16). Porém, entre o pacto e o combate final, Riobaldo também convivia com a ansiedade e a pressa: "Para mim, um palmo, àquela hora, podia medir três braças. Apertei." (p. 463) 
$\mathrm{Na}$ Bíblia, a cura de leprosos está relacionada à purificação, e suscita milagres. Lázaro, mendigo coberto de chagas da "Parábola do rico e Lázaro" (Lucas, 16: 19-31), teve a recompensa post-mortem de não padecer no Inferno. Apesar de o texto bíblico não nomear sua doença, é essa, provavelmente, a fonte da nomeação da lepra como "mal-de-lázaro", e não o episódio, mais conhecido, da ressurreição de outro Lázaro, irmão de Marta e Maria (João, 11: 1-44). Um episódio de cura da lepra é narrado com variações em Mateus, 8: 2-4; Marcos, 1: 40-45 e Lucas, 5: 12-16. Jesus teria operado o milagre dizendo: "Eu quero, sê purificado!"

Entendida, genericamente, como "o mal do mundo", que deveria ser extinto, a lepra representa no episódio uma ameaça que um chefe de jagunços, mesmo o mais poderoso deles, não poderia resolver. Por isso, ocorre a Riobaldo seguir o exemplo de Medeiro Vaz, cortando o mal pela raiz. Riobaldo não pensa em matar para pôr fim ao sofrimento do indivíduo que estava a sua frente. A individualização da dor daquele leproso é substituída pela suposição de que ele, cobra traiçoeira, pudesse repetir o feito do outro, que lambia as goiabas para disseminar o mal.

Riobaldo nada sabia do passado daquele homem. Mesmo assim, dá o seu veredito: “Seu corpo, sua culpa!" Quando ele está mais resolvido a matar, nova advertência impede a sua ação:

Tornei a empunhar o revólver. Mas completei, eu mesmo, aquilo que Diadorim decerto ia me responder: "Riobaldo, tu mata o pobre, mas, ao menos, por não desprezar, mata com tua mão cravando faca - tu vê que, por trás do podre, o sangue do coração dele é são e quente..." (p. 461-462)

Mesmo circulando em alguém de carne "impura", o sangue quente seria a prova de humanidade. Matar à faca, além de ser mostra de coragem, é um modo mais primitivo, que se insere melhor na atmosfera cavaleiresca. Depois de resistir três vezes a seu desejo de matar, o primeiro assassinato cometido por Riobaldo aconteceu durante a travessia vitoriosa do Liso do Suçuarão. O jagunço Treciziano ("O demo?") atacou Riobaldo com uma faca, e foi degolado. Treciziano é apresentado como homem "fraco de paciências", de quem diziam que "criava dor-de-cabeça", e que "padecia de erupções e dartros". Novamente, as doenças de pele aparecem relacionadas ao mal. Ao narrar, Riobaldo reflete sobre o horror que sentiu ao ver o sangue do degolado: 
Aquele, em minha roupa, a plasta vermelha fétida. Do sangue alheio que grosso me breava, mal me alimpei o queixo; eu, desgostoso de sangue, mas deixava, de sinal? Ah, não, pois ali me salteou o horror maior. Sangue... Sangue é a coisa para restar sempre em entranhas escondida, a espécie para nunca se ver. Será por isso também que imensa mais é a oculta glória de grandeza da hóstia de Deus no ouro do sacrário - toda alvíssima! - e que mais venero, com meus joelhos no duro chão. (p. 480)

As alusões ao corpo de Cristo (hóstia) e à pureza do branco, contrastando com o vermelho vivo do sangue, além de serem referências de fundo cristāo, insistem na simbologia do corpo e do sangue, que no episódio selecionado se constituem em lugar de outra forma de transubstanciação. Ao contrário da alteração da matéria que transforma a hóstia e o vinho em corpo e sangue de Cristo, deparamo-nos com aquela que transforma o "homem humano" em "coisa desumana". Em vez de aproximar do sagrado, tal transubstanciação reifica, desumaniza o leproso.

\section{De cavaleiros e de virgens}

A cena do encontro com o leproso, ao contrário daquelas que a antecederam, é quase totalmente silenciosa, o que contribui para o tom elevado da passagem. Riobaldo xinga o doente logo que o vê. O restante é um diálogo imaginado, reunindo trechos de uma fala anterior de Diadorim e palavras que Riobaldo supõe que Diadorim poderia dizer na ocasião. Mesmo no final, Riobaldo evita o diálogo: "[...] eu nāo consenti, a voz dele era que mais significava." A ausência de palavras e a relativa estaticidade de Diadorim e do leproso, contrastando com a movimentação atormentada do Urutu-Branco montado em Siruiz, colaboram para a atmosfera mística, que culmina na verdadeira epifania pela qual Riobaldo aproxima Diadorim à Virgem. Nessa rede simbólica, destacam-se os motivos religiosos: lazarento, serpente, árvore, fruto maldito, olhos, sangue, Virgem, fogo, vale, escapulário.

O romance de cavalaria e a atmosfera medieval são outra fonte preferencial para o registro em que é narrado o episódio. Riobaldo e Diadorim, mais do que na maioria dos outros episódios, assemelham-se, neste, a cavaleiros medievais, ou, melhor dizendo, Diadorim seria a donzela guerreira, altiva e misteriosa. Cavalcanti Proença, ao estudar o Grande sertão enquanto epopéia protagonizada por “Dom Riobaldo do Urucuia”, aproxima o episódio do leproso 
a uma história de um "romance-velho", em que uma moura, filha de leproso, escondia-se no alto de uma árvore. ${ }^{15}$ Heloisa Vilhena identifica a presença do amor cortês, idealizado, na relação entre Riobaldo e Otacília, como relação de devoção de um vassalo por sua dama. Porém, esse não seria um amor impossível, como o amor cortês, que é adúltero por princípio. O impedimento era de outra ordem: estaria no amor por Diadorim.

O imaginário cristão e o imaginário medieval são as fontes de quase toda a figuração, mas se trata de uma reunião de arquétipos que multiplica as possibilidades de leitura. A partir do conhecimento da Alquimia, do Hermetismo e do Tao, Francis Utéza, autor de JGR: Metafísica do Grande sertão, realizou uma interessante leitura do episódio, que é parte do capítulo intitulado "A grande mãe e o andrógino". Segundo Utéza, o Urutu-Branco teria em si um pólo feminino que compensava os excessos das energias masculinas de que o Chefe é portador. Quanto à participação de Diadorim, Utéza afirma: "A Virgem Guerreira contribui desta forma para a depuração do Urutu-Branco: salvando o mais fraco dentre seus filhos, Ela se afastava do mais forte, que podia assim partir de novo à testa de seus homens, em melhores condições para os levar à "glória'."16

Como apontou Roberto Schwarz, comparando o Grande sertão ao Dr. Faustus, de Thomas Mann, a desordenação narrativa é estratégica, pois cada ponto particular da história contém a problemática da história como um todo. Schwarz afirma que essa estratégia narrativa "faz que a história corra, para quem lê, como se obedecesse a um nexo teleológico". ${ }^{17} \mathrm{O}$ episódio do leproso, inserido numa parte do romance em que uma longa seqüência é narrada com obediência à cronologia, antecipa a revelação do verdadeiro sexo de Diadorim, e, mais importante, de sua virgindade.

A epifania que completa a cena, depois da fuga do leproso, reforça 0 aspecto elevado, e traz consigo a dualidade da simbologia da Virgem. Representando a alma unificada, em que Deus pode gerar-se a si próprio, a Virgem pertence ao sagrado. Conforme apontou Heloisa Vilhena, a devoção a Maria, que começou no final do século 11 , juntamente com o surgimento do amor cortês, traduz uma "reorientação da teologia para o tema da humanidade do Cristo", de sua encarnação. ${ }^{18}$

15 PROENÇA, Manuel Cavalcanti. Dom Riobaldo do Urucuia, cavaleiro dos Campos Gerais. In: ROSA, Guimarães. Fiç̧ão completa. Rio de Janeiro: Nova Aguilar, 1994. v. 1. p. 93.

16 UTÉZA, op. cit., p. 363.

17 SCHWARZ, op. cit., p. 47.

18 ARAUJO, op. cit., p. 353. 
O Urutu-Branco encontrou-se, por instantes, entre o inumano do corpo em chagas do leproso e o ambíguo corpo de Diadorim: humano e masculino, divino e feminino. Nesse momento, Riobaldo viu o inferno.

[...] Como que eu estava separado dele por um fogueirão, por alta cerca de achas, por profundo valo, por larguez enorme dum rio em enchente. De que jeito eu podia amar um homem, meu de natureza igual, macho em suas roupas e suas armas, espalhado rústico em suas ações?!

Essa visão, repondo a suposta igualdade de corpos entre Riobaldo e Diadorim, poderia ter operado o retorno imediato ao cotidiano, "café já coado, cavalaria em fila para a viagem". Nesse momento, porém, Riobaldo atira seu escapulário para o amigo, e Diadorim pega-o no ar, selando a cumplicidade sem a qual o lazarento possivelmente teria sido executado. (Houve quem interpretasse essa cena como despojamento total de Riobaldo, que, dali para a frente, dispensaria qualquer amuleto.)

O escapulário tinha valor maior, para Riobaldo, que seu cordão de verônicas e alguns breves que ele possuía desde menino. Riobaldo não hesitou em entregar o cordão e os breves a Seô Habão, homem ganancioso perante quem sentia ameaçada sua liberdade. Entregou-os, para mostrar-se superior; mas não lhe entregaria o escapulário:

Aquele escapulário, dito, que conservava pétalas de flor, em pedaço de toalha de altar recosturadas, e que consagrava um pedido de benção à minha Nossa Senhora da Abadia. Que, mesmo, mais tarde, tornei a pendurar, num fio oleado e retrançado. Esse eu fora não botava, ah, agora podia desdeixar não. Inda que ele me reprovasse, em hora e hora, tantos meus malfeitos, indas que assim requeimasse a pele de minhas carnes, que debaixo dele meu peito todo torcesse que nem pedaço quebrado de má cobra. (p. 411)

Atirado a Diadorim, que não o deixou cair, o escapulário foi encontrado com ele no momento de sua morte. Câmara Cascudo faz referência a uma superstição, corrente no Brasil no primeiro terço deste século (época da ação do romance), segundo a qual media-se um cordel do queixo à testa de uma moça. Tentava-se colocá-lo, amarrado, no pescoço dela. Se o cordão passasse, con- 
cluía-se que ela era virgem. ${ }^{19}$ Riobaldo corta o cordão antes de jogá-lo, impedindo a analogia entre o narrado e a superstição. De toda forma, o objeto mágico atirado por impulso soma-se à visão epifânica para unir a virgem Maria Deodorina à Virgem Maria.

Corpos afastados pela diferença hierárquica, pela velocidade de Siruiz, pela igualdade de roupas e de armas, os cavaleiros retornam ao cotidiano. Antes, porém, Diadorim cavalga em direção contrária, o que gera um princípio de tensão. O suspense da ameaça de afastamento de Diadorim colabora para que o episódio tenha uma estrutura narrativa bem fechada, à maneira de verdadeiro conto dentro do romance, com direito a mais de um momento de clímax.

O final é lírico: Diadorim apenas retornara, para, gentilmente, recolher o revólver do amigo. A cumplicidade possível naquele momento apazigua Riobaldo, relativiza seu "nojo do humano". A cena se encerra com um canto feliz ("me cantei"). Comparem-se os dois trechos seguintes:

Que é que adiantava que, àquela hora, os passarinhos cantassem, acabando de amanhecer o campo sertão? A enquanto sobejasse de viver um lázaro assim, mesmo muito longe, neste mundo, tudo restava em doente e perigoso, conforme homem tem nojo é do humano. (p. 461)

Daí, cantei. Mesmo mal, me cantei - por causa que via que, medeando tão grandes silêncios, era que Diadorim tomava mais sorrateiro poder em meu afeto, que não era possível concernente. (p. 463)

A felicidade possivel chega com o afeto, mesmo que esse sentimento precise de malícia para se instalar, driblando, sorrateiramente, a frieza do chefe. O leproso teve tempo de escapar: a lepra, o mal e a culpa continuaram a existir, mas o poderoso Urutu-Branco não precipitou o destino. A resistência à tentação fortaleceu-o enquanto chefe; logo ele conheceria sua maior vitória e sua maior derrota. Dentre as limitações do humano, existem as doenças que corroem a pele, e existem corpos encarcerados em vestes e culpas, em nome de alguma verdade estrategicamente silenciada. Riobaldo prosseguia conhecendo e reconhecendo. Mais tarde, com o desfecho trágico, velaria o corpo revelado.

19 CASCUDO, Luís da Câmara. História dos nossos gestos. Belo Horizonte: Itatiaia/ São Paulo: Edusp, 1987. p. 120. 
BUENO. R. I. Urutu-Branco c o leproso: corpo...

Como escreveu Italo Calvino, minimizar o sofrimento inevitável de quem habita o inferno dos vivos exige atenção e aprendizagem contínuas, para "tentar saber reconhecer quem e o que, no meio do inferno, não é inferno, e preservá-lo". 20

O pacto - haja o que tenha havido naquelas veredas - não impediu que Riobaldo prosseguisse em sua aprendizagem, nem o tornou menos sensível para as coisas de beleza, que merecem ser preservadas: passarinhos cantando quando amanhece o campo sertão, olhos verdes de Diadorim, canto de conciliação consigo próprio e com a natureza humana.

\section{RESUMO}

Este artigo enfoca um episódio de Grande sertāo: veredas, de Guimarães Rosa, no qual o protagonista Riobaldo, então denominado Urutu-Branco, encontra um leproso e sofre a tentação de matá-lo a fim de, como ele próprio afirma, "emendar o defeituoso". Esse episódio é exemplar quanto à tematização da culpa relacionada ao corpo; sua análise possibilita inserir esse tema na questão central de Grande serião: veredas, a da existência (ou não) de Deus e do Diabo.

Palavras-chave: ficção brasileira do século 20, Guimarães Rosa, Grande sertão: veredas.

\section{ABSTRACT}

This article focuses an episode from Grande sertão: veredas, by Guimarães Rosa, that refers to the meeting of Riobaldo - the main character - with a leper. During the meeting, Riobaldo (who was then named Urutu-Branco) is lead into the temptation of killing the leper in order to "mend the defective", as he says. This episode exemplifies well the theme of guilty related to the body. Analysing it makes possible to insert that theme into the main question of Grande sertão: veredas: is there God and Devil?

Key words: 20th century Brazilian fiction, Guimaräes Rosa, Grande sertão: veredas.

20 CALVINO, Italo. As cidades invisiveis. São Paulo: Companhia das Letras, 1990. p. 150. 


\section{REFERÊNCIAS BIBLIOGRÁFICAS}

ALBERGARIA, Consuclo. Bruxo da linguagem no Grande sertão. Rio de Janeiro: Tempo Brasileiro, 1977.

ALIGHIERI, Dante. A divina comédia. Lisboa: Sá da Costa, 1955.

ARAUJO, Heloisa Vilhena de. O roteiro de Deus. São Paulo: Mandarim, 1996.

ARRIGUCCI Jr., Davi. O mundo misturado; romance e experiência em Guimarães Rosa. In: América Latina: Palavra, Literatura e Cultura, v. 3.

AUERBACH, Erich. Mimesis; a representação da realidade na litcratura ocidental. São Paulo: Perspectiva, 1976. Coleção Estudos, n. 2.

BÍBLIA. Português. Bíblia sagrada. 54. ed. Trad. de Centro Bíblico Católico. São Paulo: Ave Maria, 1987.

CALVINO, Italo. Seis proposłas para o próximo milênio. São Paulo: Companhia das Letras, 1990.

CANDIDO, Antonio. $\mathrm{O}$ homem dos avessos. In: . Tese e antítese. São Paulo: Nacional, 1964.

CASCUDO, Luís da Câmara. História dos nossos gestos. Belo Horizonte: Itatiaia/ São Paulo: Edusp, 1987.

CHEVALIER, Jean; GHEERBRANT, Alain. Dicionário de símbolos. Rio de Janeiro: J. Olympio, 1989.

GALVÃO, Walnice Nogueira. As formas do falso. São Paulo: Perspectiva, 1986. Série Debates, n. 51.

PROENÇA, Manuel Cavalcanti. Dom Riobaldo do Urucuia, cavaleiro dos Campos Gerais. In: ROSA, Guimarães. Fiç̧ão completa. Rio de Janeiro: Nova Aguilar, 1994.

ROCHA, Marília Librandi. As espantosas palavras: uma análise de Grande sertão: veredas. São Paulo, 1997. Dissertação (Mestrado em Letras) - FFLCH, Universidade de São Paulo.

ROSA, Guimarães. Primeiras estórias. Rio de Janeiro: Nova Fronteira, 1985. . Grande serião: veredas. Rio de Janeiro: Nova Fronteira, 1986. Fiç̧ão completa. Rio de Janeiro: Nova Aguilar, 1994.

SCHWARZ, Roberto. A sereia e o desconfiado. São Paulo: Duas Cidades, 1981.

SERRA, Tania Rebelo Costa. Riobaldo Rosa: a vereda junguiana do Grande seriáo. Brasilia: Thesaurus, 1990.

UTÉZA, Francis. JGR: metafísica do Grande serıão. São Paulo: Edusp, 1994. 